\title{
PENINGKATAN KREATIVITAS MAHASISWA MELALUI PEMBELAJARAN BERBASIS PROJEK PADA MATA KULIAH SISTEM DISTRIBUSI TENAGA LISTRIK
}

\author{
Dadang Mulyana, Arif Rahman, dan Mustamam \\ Pendidikan Teknik Elektro, Fakultas Teknik, Universitas Negeri Medan \\ E-mail :dadang@unimed.ac.id
}

\begin{abstract}
ABSTRAK
Penelitian ini bertujuan mengembangkan panduan pembelajaran untuk meningkatkan kreativitas mahasiswa dalam penyelesaian tugas projek mata kuliah Sistem Distribusi Tenaga Listrik melalui model Pembelajaran Berbasis Projek (PBL). Projek yang akan dijadikan objek tugas meliputi empat komponen dalam Sistem Distribusi Tenaga Listrik yaitu (1) Komponen Jaringan Sistem Distribusi Tenaga Listrik, (2) Transformator Distribusi Tenaga Listrik, (3) Beban dalam Distribusi Tenaga Listrik, dan (4) Perencanaan Jaringan Distribusi Tenaga Listrik. Untuk mencapai tujuan penelitian ini, maka penelitian secara keseluruhan menggunakan metode penelitian dan pengembangan (research and development). Sesuai model pendekatan research and development (R\&D) maka pelaksanaan penelitian ini mengikuti langkah-langkah sebagai berikut: studi pendahuluan, perencanaan materi tugas projek, uji pakar materi tugas projek, dan diseminasi. Dalam pelaksanaan pengembangan empat komponen tugas dilakukan melalui observasi lapangan dengan melibatkan 20 mahasiswa sebagai responden dan observer. Dalam tahap pertama penelitian ini dikembangkan analisis konten terkait topik dan sub topik materi tugas projek untuk meningkatkan kreativitas mahasiswa sesuai dengan tugas yang telah disusun. Bahan studi pendahuluan terhadap keempat komponen tugas merupakan pengembangan hasil penelitian sebelumnya dalam pengembangan bahan ajar Sistem Distribusi Tenaga Listrik yang telah disusun. Hasil penelitian menyimpulkan bahwa model PBP sangat membantu mahasiswa dalam pengembangan wawasan dan kreativitasnya melalui observasi langsung dilapangan. Materi bahan ajar yang disajikan membantu mahasiswa dalam mempelajari berbagai komponen sistem distribusi tenaga listrik yang digunakan di lapangan. Sedangkan panduan pembelajaran membantu mahasiswa dalam melakukan observasi lapangan, sehingga berbagai komponen terkait sistem jaringan distribui menjadi bahan diskusi dan pengembangan materi perkuliahan.
\end{abstract}

\section{Key word: Efektivitas, Pembelajaran Berbasis Projek (PBP), Sistem Distribusi Tenaga Listrik}

\section{PENDAHULUAN}

Kerangka Kualifikasi Nasional Indonesia (KKNI) adalah suatu rujukan nasional untuk meningkatkan mutu dan daya saing bangsa Indonesia di sektor SDM melalui capaian kualifikasi SDM yang dihasilkan oleh sistem pendidikan, sistem pelatihan kerja nasional, dan sistem penilaian kesetaraan pembelajaran (Mendiknas, 2010:i). KKNI disyahkan berdasarkan Perpres No. 8 Tahun 2012. Dengan diundangkannya KKNI, berarti semua kurikulum wajib diperbarui menyesuaikan dengan KKNI.

Kehadiran KKNI berarti juga program untuk mengadakan evaluasi kurikulum. Evaluasi kurikulum didefinisikan sebagai proses yang sistematis untuk mengumpulkan, menganalisis dan menentukan informasi mengenai aspek kurikulum untuk menentukan kelemahan dan perbaikan kurikulum tersebut. Evaluasi kurikulum bisa dilakukan dalam skala kecil maupun besar, mulai dari isi kurikulum, bahan ajar, pembelajaran di kelas, dan buku teks. Titik tekan evaluasi kurikulum ialah pada rumusan tujuan pembelaharan, kompetensi, standar kompetensi, dan rancangan perangkat pembelajaran yang merujuk pada kurikulum tersebut (Salim, 2012; Budiharso, 2015).

KKNI $\begin{gathered}\text { Pengembangan } \\ \text { dengan }\end{gathered}$ surikulum berbasis
memperhatikan kurikulum sebelumnya, yaitu 
Kurikulum Berbasis Kompetensi (KBK). Beberapa ketentuan penyusunan kurikulum masih tetap mengacu pada SK Mendiknas No. 232 Tahun 2000 dan SK Mendiknas No. 045 Tahun 2002 tentang Pedoman Penyusunan Kurikulum Pendidikan Tinggi. Beberapa hal yang perlu diperhatikan antara lain: (1) jumlah sks jenjang sarjana ialah 144160 sks, (2) jenjang sarjana bisa diselesaikan dalam 7 semester, (3) kelompok mata kuliah yang menunjukkan elemen kompetensi ada lima katagori: landasan kepribadian, keilmuan dan keterampilan, keahlian, perilaku berkarya, dan berkehidupan bermasyarakat. Sedangkan dalam pengembangan kompetensi dasar bidang keahlian perlu sejalan dengan KKNI. Oleh sebab itu dalam upaya mencapai sinkronisasi antara KKNI serta KDBK Bidang Konversi Energi dengan materi perkuliahan khususnya dalam mata kuliah Distribusi Tenaga Listrik perlu disusun secara baik.

Dalam upaya meningkatkan kompetensi mutu lulusan Universitas Negeri Medan, khususnya Fakultas Teknik telah berupaya secara bertahap dan terus menerus menyelaraskan kurikulum maupun sarana dan prasarana penunjang dengan kebutuhan mahasiswa. Pengembangan kurikulum pendidikan tinggi merujuk pada Kerangka Kualifikasi Nasional Indonesia (KKNI) saat ini sedang menjadi perhatian khusus di Universitas Negeri Medan (Unimed). Salah satu bagian penting dalam upaya peningkatan tersebut telah mengembangan enam tugas untuk pencapaian kelulusan mahasiswa pada setian mata kuliah, yaitu (1) tugas rutin, (2) Critical Book Report (CBR), (3) Critical Journal Review (CJR), (4) Rekayasa Ide, (5) Mini Riset, dan (6) Tugas Projek. Salah satu bagian penting dalam pelaksanaan mata kuliah Sistim Distribysi Tenaga Listrik adalah observasi lapangan karena pembelajaran sebenarnya untuk matakuliah ini ada di lapangan yaitu lingkungan sekitar berkaitan dengan ketenagalistrikan baik tegangan menengah maupun tegangan rendah. Oleh karena itu, salah satu tugas yang menunjang untuk peningkatan kompetensi mahasiswa selain kelima tugas yang lain adalah berbasis projek.
Dalam upaya penyelesaian tugas projek yang ditempuh mahasiswa maka penelitian ini yang akan dalam upaya mengembangkan perangkat pembelajaran untuk meningkatkan kreativitas mahasiswa dalam penyelesaian tugas projek mata kuliah Sistem Distribusi Tenaga Listrik melalui model pembelajaran berbasis projek (PBL). Diharapkan melalui Pembelajaran Berbasis Proyek dapat meningkatkan kreativitas mahasiswa dalam menyelsaikan tugas projek melalui observasi dan pengamatan langsung dilapangan.

\section{KAJIAN TEORITIS \\ Pembelajaran Berbasis Proyek} (Project Based Learning $=\mathrm{PBL})$ adalah metoda pembelajaran yang menggunakan proyek/kegiatan sebagai media. Mahasiswa harus melakukan eksplorasi, penilaian, interpretasi, sintesis, dan informasi untuk menghasilkan berbagai bentuk hasil belajar. Pembelajaran Berbasis Proyek merupakan metode belajar yang menggunakan masalah sebagai langkah awal dalam mengumpulkan dan mengintegrasikan pengetahuan baru berdasarkan pengalamannya dalam beraktifitas secara nyata. Pembelajaran Berbasis Proyek dirancang untuk digunakan pada permasalahan komplek yang diperlukan peserta didik dalam melakukan insvestigasi dan memahaminya. Melalui PjBL, proses inquiry dimulai dengan memunculkan pertanyaan penuntun (a guiding question) dan membimbing peserta didik dalam sebuah proyek kolaboratif yang mengintegrasikan berbagai subjek (materi) dalam kurikulum. Pada saat pertanyaan terjawab, secara langsung peserta didik dapat melihat berbagai elemen utama sekaligus berbagai prinsip dalam sebuah disiplin yang sedang dikajinya. PjBL merupakan investigasi mendalam tentang sebuah topik dunia nyata, hal ini akan berharga bagi atensi dan usaha peserta didik.

Langkah langkah pembelajaran berbasis proyek sebagai berikut, yaitu: (1) Penentuan Pertanyaan Mendasar (Start With the Essential Question). Pembelajaran dimulai dengan pertanyaan esensial, yaitu pertanyaan yang dapat memberi penugasan mahasiswa dalam melakukan suatu aktivitas. 
Dosen harus mengidentifikasi kompetensi yang harus dicapai dalam mata kuliah, kemudian dirumuskan dalam bentuk pertanyaan-petanyaan yang akan dijawab oleh mahasiswa melalui topic proyek yang direncanakan. Dosen mengarahkan mahasiswa untuk mengambil topik yang sesuai dengan realitas dunia nyata dan dimulai dengan sebuah investigasi mendalam. Dosen mengarahkan mahasiswa agar topik yang diangkat oleh mahasiswa relevan dengan kompetensi yang telah dirumuskan. (2) Mendesain Perencanaan Proyek (Design a Plan for the Project). Perencanaan dilakukan oleh mahasiswa didampingi oleh dosen, atau dilakukan secara kolaboratif antara dosen dan mahasiswa. Perencanaan berisi tentang topic yang akan di buat, aturan main, pemilihan aktivitas alat dan bahan yang diperlukan untuk membantu penyelesaian proyek, hingga pada target capaian yang akan diperoleh. Perencanaan ini akan dituangkan dalam bentuk proposal rencana proyek degan menggunakan sistematikan tertentu. Hasil perencanaan mahasiswa dinilai oleh dosen terkait dengan relevansi topic dengan komptensi yang akan dicapai, serta tingkat kelayakan usulan yang akan dikerjakan. (3) Menyusun Jadwal (Create a Schedule), Dosen merumuskan jadwal pelaksanaan tugas proyek dalam kontrak kuliah, dan selanjutnya mahasisiwa menyusun jadwal aktivitas yang dibutuhkan dalam menyelesaikan tugas proyek berdasarkan jadwal yang telah dtentukan oleh dosen. Aktivitas mahasiswa pada tahap ini antara lain: (1) membuat timeline untuk menyelesaikan proyek, (2) membuat deadline penyelesaian proyek, (3) menetunkan jadwal bimbingan yang dibutuhkan dalam pelaksanaan dan penyususnan laporan yang berhubungan dengan proyek, dan (5) merencanakan waktu desiminasi hasil kerja. (4) Memonitor pelaksanaan dan kemajuan proyek (Monitor and the Progress of the Project). Dosen bertanggungjawab untuk melakukan monitor terhadap aktivitas mahasiswa selama menyelesaikan proyek. Monitoring dilakukan dengan cara menfasilitasi mahasiswa pada setiap proses. Dosen harusr berperan sebagai mentor bagi aktivitas mahasiswa. Agar mempermudah proses monitoring, dibuat sebuah rubrik yang dapat merekam keseluruhan aktivitas yang penting, (5) Menguji Hasil (Assess the Outcome). Dosen melakukan penilaian untuk mengukur ketercapaian standar kompetensi yang diperoleh mahasiswa. Dalam mengevaluasi kemajuan masing- masing mahasiswa, dosen memberi umpan balik tentang tingkat pemahaman yang sudah dicapai. Penilaian hasil dilakukan berdasarkan laporan hasil yang disusun dan produk yang dihasilkan. Penilaian dilaksanakan melalui rubric yang tersedia, dan (6) Mengevaluasi Pengalaman (Evaluate the Experience). Pada akhir proses penyelesaian tugas, dosen meminta kepada mahasiswa untuk melakukan refleksi terhadap aktivitas dan hasil proyek yang sudah dijalankan. Proses refleksi dilakukan baik secara individu maupun kelompok. Pada tahap ini mahasiswa diminta untuk menyampaikan pengalamanya selama mengerjakan proyek.

Berdasarkan langkah-langkah penugasan proyek pada mahasiswa, maka terdapat minimal dua tagihan pokok terhadap mahasiswa yaitu: (1) laporan perencanaan proyek dan (2) laporan hasil dalam bentuk laporan tertulis dan produk yang dihasilkan.

Pembelajaran Berbasis Projek (PBP) merupakan merupakan pembelajaran otentik yang memfasilitasi mahasiswa dalam merencanakan, melaksanakan, melaporkan, dan mengevaluasi projek yang dapat diterapkan dalam kehidupan sehari-hari (Railsback, 2012). Mahasiswa didorong untuk menjalankan projek dan bekerja secara kolaboratif untuk menjalankan satu seri tugas (projek) yang pada akhirnya menghasilkan suatu produk pada akhir projek (Anonim, 2009; Petrosina, 2009), dalam hal ini adalah proposal penelitian. PBP melatih mahasiswa untuk bekerja secara kolaboratif, yang merupakan keterampilan yang diperlukan ketika memasuki dunia kerja. Mahasiswa bekerja di dalam tim sehingga belajar untuk mengembangkan keterampilan dan kreativitas dalam merencanakan projek, mengorganisasikan tim untuk melaksanakan projek, melakukan negosiasi dan membuat konsensus tentang isu-isu atau tugas yang 
akan dikerjakan serta bertanggung jawa dalam sebuah tim.

\section{Railsback (2002) menyatakan} bahwa keutungan PBP adalah untuk menyiapkan mahasiswa masuk dalam dunia kerja yag nyata, misalnya bekerja sma, merencanakan pekerjaan, mengambil keputusan, dan mengelola waktu. Kamdi (2008) menyatakan bahwa PBP dapat meningkatkan hasil belajar karena memiliki kelebihan, seperti: PBP otentik kontekstual yang akan akan memperkuat hubungan antara aktivitas dan pengetahuan konseptual yang melatarinya; mengedepankan otonomi mahasiswa; proses belajar koaboratif yang memberikan peluang mahasiswa saling membelajarkan; holistik dan interdisipliner; realistik, berorientasi memecakan permasalahan riil; dan memeberikan pengetahuan intrinsikt yang dapat menajamkan kecakapan berpikir produktif.

Berpikir kreatif merupakan pemikiran yang bersifat keaslian dan reflektif dan menghasilkan suatu produk yang komplek, selain itu untuk menilai berpikir kreatif anak-anak dan orang dewasa sering digunakan "The Tourence Test of Creative Thingking (TTCT)". tiga komponen kunci yang dinilai dalam kreativitas menggunakan TTCT adalah kefasihan (fluency), fleksibilitas dan kebaruan (orisinilitas). kefasihan mengacu pada banyaknya ide-ide yang dibuat dalam merespon sebuah perintah. fleksibilitas tampak pada perubahan-perubahan pendekatan ketika merespon perintah. kebaruan merupakan keaslian ide yang dibuat dalam merespon perintah. Hasil dari berpikir kreatif sering disebut kreativitas. Kreativitas merupakan kemampuan seseorang menghasilkan sesuatu (soal, masalah atau pengetahuan) yang pada dasarnya baru dan sebelumnya tidak dikenal oleh pembuatnya serta berbeda dari sesuatu (soal, masalah atau pengetahuan) lain yang dibuat berdasar sebuah informasi. kreativitas ditinjau dari berdasar kefasihan (fluency), fleksibilitas dan kebaruan (orisinilitas). kreativitas dalam matematika menurut Krutetskii dalam (Siswono, 2008) merupakan kemampuan (abilities) peserta didik yang berhubungan dengan suatu penguasaan kreatif mandiri matematika di bawah pengajaran matematika, formulasi mandiri masalah-masalah matematis yang tidak rumit, penemuan cara-cara dan sarana dari penyelesaian masalah, penemuan bukti-bukti teorema, pendeduksian mandiri rumus-rumus dan penemuan metode-metode asli penyelesaian masalah non standar. salah satu cara yang mungkin dapat digunakan untuk mengoptimalkan keterampilan dalam berpikir kreatif adalah dengan pemecahan masalah dan pengajuan masalah.

Pembelajaran dalam Metodologi Penelitian Pendidikan ini diarahkan untuk mengembangkan aktivitas kreatif yang melibatkan imajinasi, intuisi, dan penemuan dengan mengembangkan pemikiran divergen, orisinil, rasa ingin tahu, membuat prediksi dan dengan mencoba-coba. Selain itu dalam aspek pemikiran kreatif dalam merumuskan dan menyelesaikan model atau perencanaan pemecahan masalah. Sehingga diperlukan suatu cara yang dapat mendorong ketrampilan berpikir kreatif mahasiswa dalam belajar. Berdasarkan penelitian yang dilakukan oleh Siswono (2008: 66), siswa akan dapat berpikir kreatif jika diberikan kesempatan mengajukan permasalahan dan meecahkan masalah.

Colley (2008) mengemukakan langkah-langkah PBP meliputi mengidentifikasi dan mendefinisikan projek, mencari informasi, merencanakan projek, melaksanakan projek, mendokumtasikan dan melaporkan penemuan, dan mengevaluasi projek. Oleh karena itu, dalam matak Sistem Distribusi Tenaga Listrik Pembelajaran berbasis projek memfasilitasi mahasiswa merancang, melaksanakan, melaporkan projek observasinya, serta merefleksikannya dalam hasil belajarnya.

\section{METODOLOGI PENELITIAN}

Penelitian ini secara keseluruhan menggunakan penelitian metode research and development (Borg dan Gall, 1983). Sesuai model pendekatan research and development pelaksanaan penelitian ini mengikuti langkah-langkah: survey pendahuluan, perencanaan materi, uji materi, validasi materi, dan diseminasi. Awal penelitian dilakukan melalui pengumpulan data dilakukan melalui observasi, pencatatan 
dokumen, dan analisis konten terkait penylesaian tugas projek mata kuliah Sistem Distribusi Tenaga Listrik. Dalam tahap pertama penelitian telah dikembangkan materi bahan ajar yang sesuai dengan KKNI pada KDBK Konversi Tenaga Listrik. Pada penelitian saat ini akan dilakukan pengembangan tugas projek mata kuliah dengan pendekatan Pembelajaran Berbasis Projek (PBL).

Sistematika penelitian yang akan dilakukan dalam penelitian ini adalah sebagai berikut: (1) Analisis materi tugas projek yang terdiri dari empat topik materi mata kuliah Distribusi Tenaga Listrik yaitu (a) Kompenen Jaringan Sistem Distribusi Tenaga Listrik, (b) Tanformator Distribusi Tenaga Listrik, (c) Beban dalam Distribusi Tenaga Listrik, dan (d) Perencanaan Jaringan Distribusi Tenaga Listrik, (2) Penyusunan pedoman pelaksanaan Pembelajaran Berbasis Projek (PBL) untuk meningkatkan kreativitas mahasiswa dalam penyelesaian tugas projek pada mata kuliah Sistem Distribusi Tenaga Listrik, (3) Pelaksanaan observasi lapangan dengan menggunakan pedoman pelaksanaan Pembelajaran Berbasis Projek (PBL) dalam penyelesaian tugas projek pada mata kuliah Sistem Distribusi Tenaga Listrik, dan (4) Analisis hasil pelaksanaan observasi lapangan. Teknik pengambilan sampel menggunakan purposive random sampling, yang bertujuan akan memperhatikan subjek mahasiswa yang menjadi sasaran pembelajaran Sistem Distribusi Tenaga Listrik, serta memperhatikan kompetensi mata kuliah Sistem Distribusi Tenaga Listrik pada program studi Pendidikan Teknik Elektro. Jumlah sampel mahasiswa direncanakan sebanyak 20 orang

\section{HASIL DAN PEMBAHASAN}

\section{Hasil Penelitian}

Berdasarkan hasil analisis data observasi diketahui bahwa secara umum pembelajaran berbasis projek meningkatkan kreativitas mahasiswa dalam menyelesaikan tugas projek mata kuliah sistem distribusi tenaga listrik. Melalui tahapan pelaksanaan PBP yaitu: (1) Penentuan Pertanyaan Mendasar (Start With the Essential Question). (2) Mendesain Perencanaan
Proyek (Design a Plan for the Project). (3) Menyusun Jadwal (Create a Schedule), (4) Memonitor pelaksanaan dan kemajuan proyek (Monitor and the Progress of the Project). (5) Menguji Hasil (Assess the Outcome), dan (6) Mengevaluasi Pengalaman (Evaluate the Experience). Pada akhir proses penyelesaian tugas mahasiswa untuk melakukan refleksi terhadap aktivitas dan hasil proyek yang sudah dijalankan. Proses refleksi dilakukan baik secara individu maupun kelompok. Pada tahap ini mahasiswa diminta untuk menyampaikan pengalamanya selama mengerjakan proyek. Hasil tersebut diuraikan dalam tugas laporan sesuai hasil observasi yang dilakukan. Catatan hasil observasi menunjukkan kreativitas mahasiswa dalam menyelesaikan tugas projeknya melalui diskusi kelompok dan analisis dokumentasi melalui buku referensi dan artikel dari jurnal ilmiah.

\section{Pembahasan Penelitian}

Penerapan model pembelajaran berbasis projek bertujuan untuk meningkatkan kreativitas mahasiswa dalam menyelesaikan tugas projek berdasarkan observasi lapangan yang dilaksanakan di lapangan terkait sistem distribusi tenaga listrik. Hal tersebut sejalan dengan beberapa hasil penelitian yang dilakukan oleh beberapa peneliti terdahulu, yang menyatakan bahwa pembelajaran berbasis projek memperkenankan peserta didik untuk bekerja mandiri dalam kontruksi pembelajarannya (pengetahuan dan keterampilan baru), dan mengkulminasikannya dalam produk nyata, (Cucu Suhana dan Hanafiah (2012: 71)). Selain itu hasil penelitian Syaad Pathmantara (2016) menyimpulkan bahwa Model pembelajaran berbasis proyek dapat meningkatkan aktivitas belajar mahasiswa, dapat meningkatkan hasil belajar aspek pengetahuan, dan meningkatkan aspek sikap, serta keterampilan.

Berdasarkan hasil penelitian dan pembahasan di atas diketahui bahwa model pembelajaran berbasis projek dapat meningkatkan kreativitas dan aktivitas serta hasil belajar mahasiswa dalam menyelesaikan tugas projeknya pada mata kuliah Sistem Distribusi Tenaga Listrik. 


\section{KESIMPULAN}

Berdasarkan analisis data dan pembahasana penelitian maka dapat ditarik beberapa kesimpulan, yaitu (1) Secara umum PBP mampu meningkatkan kreativitas mahasiswa dalam menyelesaikan tugas projek yang menjadi tagihan mata kuliah Sistem Distribusi Tenaga Listrik. (2) Panduan PBL yang dibuat sesuai dengan kaidah panduan pembelajaran merupakan pedoaman bagi mahasiswa dalam membuat tugas projek MK SDTL.(3) Observasi lapangan merupakan kegiatan utama dalam pelaksanaan aplikasi PBP pada Mata Kuliah Sistem Distribusi Tenaga Listrik dan diskusi kelompok merupakan kegiatan penunjang penyelesaian tugas projek bagi mahasiswa untuk mengambil kesimpulan dari hasil kegiatan observasi, dan (4) Pelaksanaan pembelajaran berbasis projek memerlukan penyesuaian waktu sehingga pelaksanaan ke lapangan tidak mengganggu jadwal perkuliahan lainnya.

\section{Saran}

Sebagai tindak lanjut dari hasil penelitian dan kesimpulan yang diperoleh, maka penulis memberikan saran sebagai berikut (1) Penerapan PBL adalah suatu perubahan paradigma pembelajaran yang membutuhkan komitmen yang kuat dari institusi pelaksana. Komitment tersebut antara lain dalam penyediaan sarana dan prasarana pendidikan, seperti media pembelajaran, jaringan internet yang handal, buku-buku (textbook) yang memadai, jurnaljurnal ilmiah yang uptodate, ruang kelas yang memadai, (2) Dosen-dosen perlu Topik/tema tugas harus dipersiapkan dengan baik sehingga tugas projek yang akan dibahas sesuai dengan kondisi lapangan, dan (3) Mahasiswa perlu dikondisikan dengan baik agar dapat mengikuti pembelajaran berbasis projek, sehingga dapat meningkatkan kreativitasnya

\section{DAFTAR PUSTAKA}

Anonim.(2009).Project-Bassed Instruction and Learning in Adult Education. A Publication of Building Profesional Development, Partnerships for Adult Educators Project (PRONET). Pelavin Research.

Bambang Djaja. 1984. Distribution \& Power Transformator. Surabaya : B \& D.

Colley, K. (2008). Project-Based

Sciense Instruction. TheScience Teacher, 74(8):23-28.

Dadang, M, Adi Sutopo, Mustamam, Pengembangan Bahan Ajar Mata Kuliah Distribusi Tenaga Lsitrik Sesuai Kkni Untuk Meningkatkan Kompetensi Mahasiswa, Jurnal Pendidikan Teknologi dan Kejuruan: Vol. 19 No. 2 November 2017

Hanafiah \& Cucu Suhana. (2012). Konsep Strategi Pembelajaran. Bandung: Refika Aditama.

Har Suhardi, Bambang T, Teknik Distribusi Tenaga Listrik Jilid I, Direktorat Pembinaan Sekolah Menengah Kejuruan, Depdiknas, 2008

Krulik, Stephen \& Rudnick, Jesse A. (1995). The New Sourcebook for Teaching Reasoning and Problem Solving in Elementary School. Needham Heights, Massachusetts: Allyn \& Bacon.

Pehkonen, Erkki. (1997). The State-of-Art in Mathematical Creativity., Vol. 29, No. 3, 230-245.

Petrosina, A. (2009). Project-

Based- Learning: Background Knowledge and Theory. Madison: WisconsinCenter for Education Research.

Railsback, J. (2002). Project-Basic-

Learning: Creating Excitemen for

Learning. Northwest Regional Educational Laboratory. 